\title{
PENGUJIAN VALIDITAS DAN RELIABILITAS SKALA DUKUNGAN IMAN
}

\author{
Christiany Suwartono ${ }^{1}$, Junianawaty Suhendra ${ }^{2}$, Sylvia Soeherman ${ }^{2}$, \& Aileen P. Mamahit ${ }^{2}$ \\ ${ }^{1}$ Universitas Katolik Indonesia Atma Jaya, Jl. Jenderal Sudirman 51, Jakarta 12930, Indonesia \\ ${ }^{2}$ Sekolah Tinggi Teologi SAAT, Jl. Bukit Hermon No. 1, Tidar Atas, Malang, Jawa Timur 65151, Indonesia
}

Korespondensi:

le-mail: christiany.suwartono@atmajaya.ac.id

\begin{abstract}
The formation of faith in adolescents and young people is rooted in their interaction with parents, both father, and mother, as well as friends. Adolescence and young adulthood are periods of seeking faith in various aspects of life. However, there has not been a measurement of the extent to which adolescents and young people regard parents and friends as role models of their faith. This study was aimed to the Perceived Faith Support - Parents and Friends Scale to be the Scale of Faith Support. The study was conducted through convenience sampling, involving 1,390 participants from three major islands in Indonesia. The results of this adaptation proved to be reliable with internal consistency methods, especially Cronbach's Alpha and to be valid with factor analysis methods. Validation with age criteria is proven by the support of faith from the father and mother, but not with friends. The Faith Support Scale is argued to be fit for both theoretical and practical purposes. The

development and application of this scale are further discussed.
\end{abstract} Article history:

Received 17 February 2019

Received in revised form 27 March 2019

Accepted 8 April 2019

Available online 29 May 2019

\begin{abstract}
Abstrak - Pembentukan iman pada remaja dan kaum muda merupakan hasil interaksi mereka dengan orang tua, baik ayah maupun ibu, juga teman. Masa remaja dan kaum muda merupakan masa pencarian keyakinan (iman) di berbagai aspek kehidupan. Namun, belum ada pengukuran mengenai sejauh mana remaja dan kaum muda menganggap orang tua dan teman sebagai teladan iman dirinya. Studi ini bertujuan untuk mengadaptasi skala Perceived Faith Support - Parents and Friends menjadi Skala Dukungan Iman. Penelitian dilakukan dengan teknik convenience sampling dan melibatkan 1,390 partisipan dari tiga pulau besar di Indonesia. Hasil adaptasi ini terbukti reliabel dengan metode konsistensi internal, khususnya Cronbach's Alpha dan valid dengan metode faktor analisis. Validasi dengan kriteria usia terbukti pada dukungan iman dari ayah dan ibu, namun tidak dengan teman. Skala Dukungan Iman ini siap digunakan dalam konteks penelitian maupun praktis. Pengembangan dan aplikasi skala ini dibahas lebih lanjut.
\end{abstract}

Kata Kunci: faktor analisis; reliabilitas; religiositas; dukungan iman; validitas 


\section{PENDAHULUAN}

Studi mengenai spiritualitas dan religiositas merupakan area yang penting karena memiliki siginifikansi terhadap berbagai area perkembangan kaum muda (Roehlkepartain, Benson, King, \& Wagener, 2006; Sax, Astin, Korn, \& Mahoney, 1999). Perkembangan spiritualitas dan religiositas remaja dipengaruhi secara sengaja atau tidak sengaja; secara langsung atau tidak langsung oleh beberapa faktor sosial, seperti orang tua, teman, sekolah, institusi agama, literatur, kelompok, dan media (Arnett, 1995; Schwartz, 2006).

Schwartz (2006) menyoroti peran orang tua dan teman sebagai peran yang unik dan memperlengkapi dalam mendukung religiositas kaum muda, secara khusus melalui modeling (peragaan) dan dialog. Peran orang tua diperhitungkan sebagai peran yang paling penting dalam pertumbuhan religiositas seorang anak, baik melalui kehadiran (Ozorak, 1989) maupun ketidakhadiran (Hunsberger, 1985). Orang tua memberikan model perilaku yang religius. Selain orang tua, Schwartz juga menyoroti peran dari teman karena sekalipun ada dukungan secara teori mengenai peran teman yang memengaruhi religiositas kaum muda (Cooper \& Cooper Jr., 1992; Fowler, 1981; Grotevant \& Cooper, 1986), namun bukti empiris yang menunjukkan peran penting dari teman terhadap perkembangan religiositas kaum muda masih sedikit (Schwartz, Bukowski, \& Aoki, 2006).

Keluarga adalah komunitas religius yang memberikan pengaruh kuat dalam memberikan model yang dipelajari dan diikuti oleh anak-anak (Bandura, 2003; Cornwall, 1989; Oman \& Thoresen, 2003). Model perilaku ini adalah prediktor yang kuat terhadap perilaku religius anak remaja, meskipun tidak begitu kuat pengaruhnya terhadap iman kepercayaan mereka (Francis \& Gibson, 1993). Secara langsung maupun tidak langsung, orang tua menyampaikan nilai dan kepercayaan kepada anak-anak (Flor \& Knapp, 2001; Lawrence \& Valsiner, 1993). Dua model peran orang tua yang disoroti oleh Schwartz (2006) adalah transmission model (melalui peneladanan perilaku religiositas) dan transaction model (melalui percakapan iman). Okagaki, Hammond, dan Seamon (1999) menemukan bahwa modeling kepercayaan agama yang intensional dan keterlibatan dalam kegiatan religius orang tua meningkatkan keinginan para remaja untuk berbagi di dalam kepercayaan orang tua. Penemuan Okagaki dkk. (1999) didukung oleh beberapa studi (Hoge \& Petrillo, 1978; Hoge, Petrillo, \& Smith, 1982; Wilson \& Sherkat, 1994) yang menyatakan bahwa relasi yang dekat dan hangat dengan orang tua cenderung memberikan dorongan untuk anak menerima kepercayaan religius orang tuanya sebagai bagian dari sistem 
kepercayaannya juga. Lebih lanjut, ditemukan bahwa keluarga yang melibatkan anak-anaknya dalam pola ibadah mereka (berpartisipasi dalam doa, mempelajari kitab suci, memimpin diskusi, dan percakapan iman) memiliki anak-anak remaja dan pemuda yang kehidupan imannya sangat aktif (Boyatzis \& Janicki, 2003; Flor \& Knapp, 2001; Lee, Rice, \& Gillespie, 1997). Dapat disimpulkan bahwa dukungan orang tua (ayah dan ibu), baik melalui model perilaku religious (transmission model) maupun melalui percakapan iman (transactional model) merupakan variabelvariabel yang memengaruhi religiositas kaum muda (Schwartz, 2006).

Pengaruh dari teman juga mendapat perhatian dari beberapa peneliti. Hoge dan Petrillo (1978) melihat bahwa teman sebaya memberikan sedikit pengaruh terhadap religiositas melalui kebersamaan partisipasi mereka dalam kelompok di gereja. Sementara itu, de Vaus (1983) menemukan bahwa pengaruh dari teman lebih kepada sesuatu di luar religiositas, misalnya konsep diri. Schwartz (2006) menyimpulkan bahwa dalam menjalankan perannya, orang tua tidak berjalan sendiri danteman sebaya menjadi kekuatan positif yang memperkuat proses transmisi dan transaksi yang diberikan orang tua dalam pembentukan religiositas kaum muda. Selain itu, orang tua juga memiliki pengaruh dalam mengarahkan anak-anaknya untuk memiliki kelompok pertemanan yang berpengaruh positif dalam religiositas anaknya (King, Furrow, \& Roth, 2002).

Religiositas ini sangat dinamis di masa remaja karena pada periode inilah, sebagai anak muda, mereka mempelajari mengenai diri mereka sendiri dan bagaimana mereka memandang dunia di sekitar mereka (Pearce \& Denton, 2011). Remaja dengan religiositas yang tinggi diharapkan berkarakter dinamis dan integral, menempatkan iman sekaligus berbagai aspek kehidupan lainnya (Wahib, 2015). Sayangnya, pengukuran mengenai religiositas maupun dukungan iman di Indonesia amat terbatas. Hal inilah yang membuat peneliti tertarik untuk melakukan adaptasi dan mengukur skala dukungan orang tua dan teman terhadap religiositas remaja dan pemuda. Sehubungan dengan alat ukur ini membutuhkan konteks tertentu, maka peneliti memutuskan untuk mengukur religiositas remaja dan pemuda yang berafiliasi dengan agama, yaitu Kristen di Indonesia. Skala yang dipakai adalah Skala Dukungan Iman Religiositas - Ayah, Ibu, dan Teman yang diadaptasi dari skala Perceived Faith Support - Parents (PFS-P) and Friends (PFS-F) yang dikembangkan oleh Schwartz (2006). Dengan tersedianya skala ini, diharapkan dapat memberi masukan mengenai tokoh yang adekuat (apakah ayah, ibu, atau teman) bila ingin melakukan intervensi ketika melakukan pembinaan iman pada remaja.

Skala Perceived Faith Support oleh Scwartz (2006) merupakan skala untuk mengukur variabel laten besarnya penerimaan dukungan iman. Dalam pengujiannya, skala PFS-P dan PFS-F 
memiliki nilai reliabilitas yang baik untuk empat faktor yang diuji, yakni dialog iman dengan orang tua $(\alpha=.86)$, dialog iman dengan teman $(\alpha=.87)$, konsistensi perilaku orang tua dengan agama $(\alpha$ $=.90)$, dan konsistensi perilaku teman dengan agama $(\alpha=.85)$. Skala ini kemudian diterjemahkan dan diadaptasi ke dalam bahasa dan konteks Indonesia agar dapat digunakan untuk penelitian kepada remaja di Indonesia. Penelitian ini membahas tentang hasil uji validitas dan reliabilitas Skala Dukungan Iman - Ayah, Ibu, dan Teman yang telah diadaptasi. Secara umum, dengan adanya skala ini diharapkan dapat berguna untuk memberi informasi mengenai gambaran interaksi sosial kaum muda di Indonesia, khususnya dalam pengembangan iman. Secara khusus, skala yang telah diadaptasi ini diharapkan dapat menjadi alat bantu dalam mengidentifikasi masalah yang berkenaan dengan dukungan iman dari orang tua dan teman-teman, sertapengaruhnya kepada religiositas kaum muda di Indonesia. Dengan demikian, pertanyaan utama dalam penelitian ini adalah: Apakah Skala Dukungan Iman ini valid dan reliabel?

\section{METODE}

\section{Partisipan}

Karakteristik sampel dari penelitian ini adalah remaja dan kaum muda. Peneliti menggunakan klasifikasi usia menurut Kementerian Kesehatan Republik Indonesia (2009) yang mengklasifikasikan usia 12-16 tahun sebagai remaja awal, 17-25 tahun sebagai remaja akhir, dan 26-35 tahun sebagai dewasa awal. Penelitian ini menggunakan teknik convenience sampling dengan area penelitian di lima wilayah Indonesia, yaitu Kalimantan Barat, Jawa Barat, Jakarta-TangerangBekasi, Surabaya, dan Sumatera Utara. Partisipan seluruhnya beragama Kristen. Hal ini dikarenakan penelitian ini bertujuan untuk memberikan deskripsi keterlibatan orang tua dan teman dari remaja dalam pertumbuhan iman Kristen. Jumlah partisipan dalam penelitian ini adalah 1,460 partisipan, namun besar sampel dari data yang lengkap dan dapat dianalisis dalam penelitian ini adalah 1,390 partisipan. Partisipan yang berdomisili di area Kalimantan Barat sebesar 31.3 persen, Jawa Barat sebesar 27.1 persen, Jakarta-Tangerang-Bekasi sebesar 28.3 persen, Surabaya sebesar 11.4 persen, dan Sumatera Utara sebesar 1.9 persen. Partisipan berusia antara 13-27 tahun $(M=$ 16.9; $S D=3.52)$. Partisipan merupakan pelajar SMA $(41.2 \%)$, pelajar SMP $(26.8 \%)$, mahasiswa (18.6\%), dan karyawan (13.5\%). Mayoritas partisipan masih tinggal dengan orang tua kandung $(87.9 \%)$, sedangkan sisanya tinggal di kos (5.1\%), tinggal dengan salah satu dari keluarga besar 
mereka (misalnya: kakek-nenek, paman-bibi; 4.5\%), asrama (1.1\%), dan lain sebagainya. Status perkawinan orang tua partisipan yang masih menikah sebesar 90.5 persen, bercerai sebesar 3.7 persen, cerai mati sebesar 2.6 persen, berpisah sebesar 2.2 persen, keduanya sudah meninggal sebesar .3 persen, dan sisanya tidak menjawab.

\section{Prosedur}

Peneliti menghubungi para pimpinan komunitas beragama Kristen di beberapa daerah. Kemudian, peneliti meminta izin dan bantuan untuk menyebarkan kuesioner. Kepada para pimpinan yang setuju untuk membantu, peneliti menitipkan paket kuesioner untuk diisi dan mengirimkan kembali ke peneliti setelah diisi. Pengambilan data dilakukan pada bulan Juli 2018 - September 2018. Selain melalui para pimpinan komunitas dengan paket kuesioner, pengambilan data juga dilakukan dengan metode daring. Kuesioner berupa tautan (link) dan kertas disebarkan ke berbagai komunitas beragama (Kristen) di Kalimantan Barat, Jawa Barat, Jakarta-Tangerang-Bekasi, Surabaya, dan Sumatera Utara.

\section{Instrumen}

Peneliti melakukan adaptasi skala Perceived Faith Support-Parents and Friends (Schwartz, 2006) menjadi Skala Dukungan Iman - Ayah, Ibu, dan Teman. Skala ini berisi enam pernyataan dengan enam pilihan jawaban dari Tidak Pernah (skor 1), Sangat Jarang (skor 2), Jarang (skor 3), Kadang-kadang (skor 4), Sering (skor 5), dan Setiap Kali (skor 6). Dalam adaptasi ini, tidak terdapat pernyataan yang unfavorable. Peneliti mengadaptasi Skala Dukungan Iman ini untuk tiga peran, yaitu ayah, ibu, dan teman. Skala ini bertujuan untuk mengukur derajat sejauh mana partisipan merasa didukung dalam keimanan mereka melalui peneladanan (transmission model) dan percakapan iman (transaction model) dengan ayah, ibu, atau teman mereka.

\section{Teknik Analisis}

Pengujian validitas dilakukan dengan Exploratory Factor Analysis (EFA). Peneliti menggunakan analisis komponen utama sebagai metode ekstraksi dan Promax dengan Kaiser Normalization sebagai metode rotasi. Hal ini bertujuan menentukan jumlah dimensi yang sebenarnya dimiliki oleh alat tes hasil adaptasi ini. Selanjutnya, peneliti melakukan Confirmatory Factor Analysis (CFA). Untuk menentukan model fit, Hu dan Bentler (1999) menyarankan agar koefisien Tucker-Lewis Index (TLI) dan Comparative Fit Index (CFI) sama atau di atas .95, 
sedangkan Root Mean Square Error of Approximation (RMSEA) dengan koefisien kurang dari atau sama dengan .06. Setelah itu, peneliti melakukan uji reliabilitas dengan metode Cronbach's Alpha. Semua analisis dilakukan dengan bantuan program olah data. Peneliti menggunakan program IBM SPSS Statistics 22 dalam melakukan EFA dan analisis reliabilitas dengan Cronbach's Alpha. Kemudian, LISREL 8.80 untuk melakukan CFA.

Dalam melakukan pengujian reliabilitas, peneliti menggunakan teknik konsistensi internal. Teknik ini digunakan untuk memastikan bahwa butir-butir yang beragam di dalam suatu alat ukur tetap mengukur satu konstruk yang sama dan menghasilkan skor yang konsisten (Gregory, 2013). Secara khusus, peneliti menggunakan teknik Cronbach's Alpha untuk mengukur konsistensi internal dengan batasan reliabilitas minimal sama dengan .70 (Gregory, 2013).

\section{ANALISIS DAN HASIL}

Pertama, peneliti melakukan analisis apakah data yang diperoleh cocok untuk dilakukan teknik faktor analisis. Peneliti melakukan analisis Kaiser-Mayer-Olkin Measure of Sampling Adequacy (KMO-MSA) dan Bartlett's test of sphericity. Hasilnya dapat dilihat pada Tabel 1.

Tabel 1.

Kaiser-Mayer-Olkin Measure of Sampling Adequacy (KMO-MSA) dan Bartlett's Test

\begin{tabular}{lccc}
\hline & Ayah & Ibu & Teman \\
\hline KMO-MSA & .88 & .87 & .86 \\
Bartlett's Test of Sphericity & 6115.27 & 6021.13 & 4833.91 \\
Sumbangan varians faktor utama & 71.17 & 69.54 & 62.07 \\
\hline
\end{tabular}

Koefisien Kaiser-Mayer-Olkin Measure of Sampling Adequacy (KMO-MSA) di atas .50 dan Bartlett's test of sphericity yang signifikan $(p<.05)$ menunjukkan bahwa data yang diperoleh dapat diterapkan teknik analisis faktor. Kemudian, peneliti melakukan analisis dari enam pernyataan dengan teknik Exploratory Factor Analysis (EFA) untuk setiap skala: ayah, ibu, dan teman. Dengan menggunakan principle axis factor extraction dan rotasi Promax dengan Kaiser Normalization, dihasilkan satu faktor (dimensi) utama yang dapat menjelaskan nilai sebesar 71.17 persen, 69.54 persen, dan 62.07 persen dari varians religiositas untuk skala ayah, ibu, dan teman. 
Tabel 2.

Koefisien Loading Factor dari Tiap Butir Skala

\begin{tabular}{lccc}
\hline Pernyataan & Ayah & Ibu & Teman \\
\hline Saya membaca dan membahas Kitab Suci dengan [...] saya. & .739 & .704 & .761 \\
Saya berdoa bersama [...] saya. & .777 & .756 & .877 \\
Saya dan [...] saya membicarakan bagaimana menjadi orang yang beragama. & .837 & .800 & .861 \\
[...] mendorong saya untuk bertumbuh semakin dekat kepada Tuhan dengan & .817 & .834 & -.159 \\
cara saya. & & & \\
[...] menunjukkan iman kepada Tuhan dalam perkataan dan perbuatan. & .862 & .867 & .785 \\
[...] saya konsisten di dalam menghidupi imannya. & .818 & .814 & .816 \\
\hline
\end{tabular}

Keterangan: $[\ldots]=$ diisi dengan [ayah atau ibu atau teman]

Adapun korelasi antardomain hasil EFA dapat dilihat pada Tabel 3. Dari Tabel 3, dapat dilihat bahwa ketiga tipe Skala Dukungan Iman saling berkorelasi signifikan dari lemah sampai sedang (.14 - .63). Kemudian, ditemukan bahwa usia berkorelasi negatif dan signifikan dengan dukungan iman ayah $\left(r_{(1388)}=-.17 ; p<.01 ; r^{2}=.03\right)$ dan ibu $\left(r_{(1388)}=-.10 ; p<.01 ; r^{2}=.01\right)$, namun kekuatan korelasinya lemah (cenderung hampir tidak ada). Selain itu, tidak ada hubungan yang signifikan antara usia dengan dukungan iman dari teman.

Tabel 3.

Hasil Korelasi Antar-Skala Dukungan Iman

\begin{tabular}{lccc}
\hline & $\begin{array}{c}\text { Dukungan Iman } \\
\text { Ayah }\end{array}$ & $\begin{array}{c}\text { Dukungan } \\
\text { Iman Ibu }\end{array}$ & $\begin{array}{c}\text { Dukungan Iman } \\
\text { Teman }\end{array}$ \\
\hline Dukungan Iman Ayah & 1 & & \\
Dukungan Iman Ibu & $.628^{* *}$ & 1 & \\
Dukungan Iman Teman & $.138^{* *}$ & $.197^{* *}$ & 1 \\
Usia & $-.170^{* *}$ & $-.097^{* *}$ & .025 \\
\hline
\end{tabular}

Catatan: **. Korelasi signifikan pada LoS .01 (dua arah)

Setelah melakukan EFA, peneliti melanjutkan dengan melakukan Confirmatory Factor Analysis (CFA). Peneliti menguji model satu struktur faktor dari alat tes ini, sesuai dengan analisis EFA yang dilakukan.

Tabel 4.

Goodness-of-Fit Indices dari Hasil Confirmatory Factor Analysis

\begin{tabular}{llllllllll}
\hline Model & $\boldsymbol{\chi}^{\mathbf{2}}$ & $\mathbf{d f}$ & $\boldsymbol{\chi}^{\mathbf{2}} \mathbf{d f}$ & $\mathbf{R M S E A}$ & $\mathbf{C F I}$ & AIC & SRMR & TLI & AGFI \\
\hline Ayah & 12.33 & 3 & 4.11 & .049 & 1 & 48.33 & .005 & 1 & .98 \\
Ibu & 15.33 & 5 & 3.07 & .040 & 1 & 47.33 & .007 & 1 & .98 \\
Teman & 21.52 & 6 & 3.59 & .044 & 1 & 51.52 & .013 & .99 & .98 \\
\hline
\end{tabular}

Catatan: Semua nilai p untuk $\chi^{2}$ signifikan pada LoS 0.01 
Berdasarkan rasio $\chi^{2} / d f$, koefisien CFI, TLI, dan AGFI, peneliti mendukung unidimensionalitas Skala Dukungan Iman ini. Hasil ini sejalan dengan hasil EFA yang juga menunjukkan bahwa alat tes ini memiliki satu faktor.

Langkah selanjutnya, peneliti melakukan analisis reliabilitas berdasarkan temuan faktor analisis yang disajikan pada Tabel 5.

Tabel 5.

Reliabilitas Skala Dukungan Iman

\begin{tabular}{lccccc}
\hline & Cronbach's Alpha & SEM & $\begin{array}{c}\text { Jangkauan } \boldsymbol{r} \\
\text { corrected item-total }\end{array}$ & M & SD \\
\hline Ayah & .92 & 2.39 & $.70-.82$ & 18.40 & 8.46 \\
Ibu & .91 & 2.40 & $.68-.81$ & 21.97 & 8.00 \\
Teman & .78 & 2.59 & $-.15-.78$ & 25.20 & 5.53 \\
\hline
\end{tabular}

Berdasarkan teknik Cronbach's Alpha, hasil uji reliabilitas skala mengindikasikan bahwa butir-butir Skala Dukungan Iman memiliki konsistensi internal yang tinggi (sudah > .70; Gregory, 2013). Meskipun masih ada koefisien korelasi butir dengan total yang negatif (butir mengenai membaca dan membahas kitab suci untuk Skala Dukungan Iman - Teman), namun secara keseluruhan skala masih dalam batas reliabel, maka peneliti memutuskan untuk mempertahankan butir tersebut.

\section{DISKUSI}

Skala Dukungan Iman yang diadaptasi merupakan skala yang unidimensi dan berbeda dengan skala originalnya, yaitu Skala Perceived Faith Support oleh Schwartz (2006). Pengadaptasian dilakukan dengan pengurangan masing-masing dua pernyataan yang mengukur faktor keteladanan dan sikap, serta kepercayaan akan agama yang dianut. Peneliti mengeliminasi butir faktor keteladanan ('Orang tua menunjukkan kepada saya arti menjadi seorang Kristen yang otentik.') karena menurut peneliti faktor ini yang akan diukur oleh Skala Dukungan Iman, sehingga peneliti merasa pernyataan ini menjadi pengulangan yang tidak diperlukan. Kemudian, untuk butir sikap dan kepercayaan ('Saya setuju dengan sikap dan kepercayaan dari orang tua saya.') merupakan variabel yang dikontrol dalam penelitian ini. Partisipan penelitian merupakan remaja dengan agama yang sama dengan orang tua mereka, dalam hal ini Kristen. Dengan adanya butir ini, maka tidak akan ada variasi jawaban dari partisipan. Pengurangan kedua butir ini menjadikan 
masing-masing skala memiliki enam pernyataan untuk mengukur dukungan iman dari orang tua dan teman. Enam pernyataan mengenai dukungan iman dari orang tua dibedakan antara dukungan iman dari ayah dan ibu mengingat besarnya kemungkinan perbedaan persepsi anak mengenai dukungan iman yang diterima dari ayah dibandingkan dari ibu karena presensi atau absensi salah satu orang tua, dan lain-lain. Jadi, terdapat 18 pernyataan dalam skala ini untuk mengukur dukungan religius dari ayah, ibu, dan teman.

Dari hasil korelasi antarskala dukungan iman (ayah, ibu, dan teman) dengan usia, didapatkan hasil korelasi terbesar yang diperoleh dari dukungan iman dari ibu dan ayah. Sedangkan, faktor usia berkorelasi negatif dan signifikan dengan dukungan iman ayah dan ibu, namun efeknya lemah dan tidak signifikan dengan dukungan iman dari teman. Korelasi yang negatif dan signifikan antara usia dengan dukungan iman dari ayah dan ibu menandakan Skala Dukungan Iman ini valid secara kriteria, yaitu usia. Ayah dan Ibu cenderung lebih mendukung pertumbuhan remaja ketika mereka masih kecil dan semakin bertambahnya usia remaja, mereka akan 'melepas' dukungan iman mereka. Hal ini menandakan bahwa semakin bertambahnya usia, remaja diharapkan dapat memupuk imannya sendiri. Hal ini juga berkaitan dengan masa pencarian diri remaja. Sampai titik tertentu, remaja didukung dan dibantu orang tuanya dalam menentukan nilai (iman) dirinya (Hurlock, 1980; Moretti \& Peled, 2004; Santrock, 2009). Dukungan iman dari teman tidak memiliki hubungan yang signifikan dengan usia, sehingga hal ini menandakan remaja tidak bergantung pada teman untuk dukungan iman. Temuan ini berbeda dari beberapa penelitian sebelumnya yang menyatakan bahwa kelompok pertemanan remaja memiliki pengaruh terhadap religiositas (Hoge \& Petrillo, 1978; King dkk. 2002), namun mendukung hasil dari penelitian de Vaus (1983).

Peneliti melakukan adaptasi skala Perceived Faith Support_-Parent and, Friends (Schwartz, 2006) menjadi Skala Dukungan Iman yang terdiri dari tiga variasi peran, yaitu dukungan iman dari ayah, ibu, dan teman. Namun, berbeda dengan Schwartz, peneliti tidak mencantumkan dua butir dari faktor model iman. Dari hasil validasi menggunakan teknik analisis faktor eksploratori yang dilanjutkan dengan konfirmatori, ditemukan bahwa skala ini adalah unidimensi dan valid. Dengan demikian, struktur skala ini berbeda dengan Schwartz yang menemukan dua faktor.

Reliabilitas dari Skala Dukungan Iman ini reliabel dengan menggunakan teknik Cronbach's Alpha. Hasil koefisien reliabilitas adaptasi Skala Dukungan Iman ini lebih tinggi daripada hasil penelitian Schwartz (2006). Terdapat satu butir dari Skala Dukungan Iman dari Teman mengenai membaca dan membahas kitab suci yang berkorelasi negatif. Hal ini dapat dipahami mengingat partisipan penelitian rata-rata berusia 17 tahun, di mana masa remaja ini penuh dengan dinamika 
kehidupan lain, baik sekolah maupun persahabatan. Oleh karena itu, ketika bertemu dengan teman, mereka enggan untuk membahas kitab suci. Sedangkan, keluarga memang memberikan pengaruh yang kuat, dalam hal ini ayah dan ibu untuk diteladani (Bandura, 2003; Cornwall, 1989; Oman \& Thoresen, 2003).

\section{SIMPULAN DAN SARAN}

\section{Simpulan}

Skala Dukungan Iman versi Indonesia ini memiliki satu dimensi yang valid berdasarkan pengujian validasi konstruk dengan metode faktor analisis. Selain itu, skala ini juga valid dengan metode Cronbach's Alpha. Dengan demikian, skala ini dapat digunakan untuk mengukur dukungan iman dari orang tua dan teman secara valid dan reliabel.

\section{Saran Teoretis}

Adaptasi Skala Dukungan Iman ini merupakan bagian dari penelitian yang bertujuan mendapatkan gambaran keimanan komunitas kaum muda Kristen. Hal ini menyebabkan adaptasi memiliki karakteristik sampel yang spesifik, yaitu kaum muda beragama Kristen. Pada penelitian selanjutnya, dapat dilakukan penelitian dengan karakteristik sampel partisipan yang beragama selain Kristen, sehingga dapat diketahui kegunaan dari skala ini secara lintas agama. Selain itu, pengambilan data dapat diperluas di daerah Indonesia lainnya, seperti Indonesia bagian Timur, sehingga dapat diketahui apakah skala ini dapat mengukur dukungan iman di berbagai budaya yang bervariasi di Indonesia.

\section{Saran Praktis}

Keluarga (terutama orang tua) dan teman merupakan pihak yang paling diharapkan memberikan kontribusi dalam pembinaan watak dan perilaku dari remaja dan kaum muda. Dengan adanya Skala Dukungan Iman ini, dapat diketahui tokoh yang memiliki peranan lebih terhadap seorang kaum muda. Informasi mengenai tokoh yang signifikan berperan dalam mendukung perkembangan iman kaum muda ini akan berguna dalam pembuatan modul intervensi, bahkan praktik konseling atau pelatihan. Dengan adanya Skala Dukungan Iman yang valid dan reliabel ini, tentunya dapat berkontribusi dalam mengidentifikasi tokoh yang signifikan tersebut dengan lebih percaya diri. 


\section{UCAPAN TERIMA KASIH}

Terima kasih kepada Lembaga Penelitian dan Pengabdian kepada Masyarakat Sekolah Tinggi Teologi SAAT yang telah mengkoordinasikan penelitian ini.

\section{REFERENSI}

Arnett, J. J. (1995). Broad and narrow socialization: The family in the context of a cultural theory. Journal of Marriage and the Family, 57(3), 617-628. doi: 10.2307/353917

Bandura, A. (2003). On the psychosocial impact and mechanisms of spiritual modeling: Comment. International Journal for the Psychology of Religion, 13(3), 167-173. doi: 10.1207/S15327582IJPR1303_02

Boyatzis, C. J., \& Janicki, D. L. (2003). Parent-child communication about religion: Survey and diary data on unilateral transmission and bi-directional reciprocity styles. Review of Religious Research, 44(3), 252-270. doi: 10.2307/3512386

Cooper, C. R., \& Cooper, R. G., Jr. (1992). Links between adolescents' relationships with their parents and peers: Models, evidence, and mechanisms. Dalam R. D. Parke \& G. W. Ladd (Eds.), Family-peer relationships: Modes of linkage (hlm. 135-158). Hillsdale, NJ: Lawrence Erlbaum Associates, Inc.

Cornwall, M. (1989). The determinants of religious behavior: A theoretical model and empirical test. Social Forces, 68(2), 572-592. doi: 10.2307/2579261

de Vaus, D. A. (1983). The relative importance of parents and peers for adolescent religious orientation: An Australian study. Adolescence, 18(69), 147-158.

Flor, D. L., \& Knapp, N. F. (2001). Transmission and transaction: Predicting adolescents' internalization of parental religious values. Journal of Family Psychology, 15(4), 627-645. doi: $10.1037 / 0893-3200.15 .4 .627$

Fowler, J. W. (1981). Stages of faith: The psychology of human development and the quest for meaning (6th ed.). San Francisco, CA: Harper \& Row.

Francis, L. J., \& Gibson, H. M. (1993). Parental influence and adolescent religiosity: A study of church attendance and attitude toward Christianity among adolescents 11 to 12 and 15 to 16 
years old. The International Journal for the Psychology of Religion, 3(4), 241-253. doi: 10.1207/s15327582ijpr0304_4

Gregory, R. J. (2013). Psychological Testing: History, principles, and applications (7th ed.). Upper Saddle River, NJ: Pearson.

Grotevant, H. D., \& Cooper, C. R. (1986). Individuation in family relationships: A perspective on individual differences in the development of identity and role-taking skill in adolescence. Human Development, 29(2), 82-100. doi: 10.1159/000273025

Hoge, D. R., \& Petrillo, G. H. (1978). Development of religious thinking in adolescence: A test of Goldman's theories. Journal for the Scientific Study of Religion, 17(2), 139-154. doi: $10.2307 / 1386157$

Hoge, D. R., Petrillo, G. H., \& Smith, E. I. (1982). Transmission of religious and social values from parents to teenage children. Journal of Marriage and the Family, 44(3), 569-580. doi: $10.2307 / 351580$

Hu, L., \& Bentler, P. (1999). Cutoff criteria for fit indixes in covariance structure analysis: Conventional criteria versus new alternatives. Structural Equation Modeling, 6(1), 1-55. doi: $10.1080 / 10705519909540118$

Hunsberger, B. (1985). Religion, age, life satisfaction, and perceived sources of religiousness: A study of older persons. Journal of Gerontology, 40(5), 615-620. doi: 10.1093/geronj/40.5.615

Hurlock, E. B. (1980). Psikologi perkembangan: Suatu pendekatan sepanjang rentang kehidupan (5th ed.). Jakarta: Erlangga.

Kementerian Kesehatan Republik Indonesia. (2009). Profil kesehatan Indonesia 2009. Ditemu kembali dari http://www.depkes.go.id/resources/download/pusdatin/profil-kesehatanindonesia/profil-kesehatan-indonesia-2009.pdf

King, P. E., Furrow, J. L., \& Roth, N. (2002). The influence of families and peers on adolescent religiousness. Journal of Psychology and Christianity, 21(2), 109-120.

Lawrence, J. A., \& Valsiner, J. (1993). Conceptual roots of internalization: From transmission to transformation. Human Development, 36(3), 150-167. doi: 10.1159/000277333

Lee, J. W., Rice, G. T., \& Gillespie, V. B. (1997). Family worship patterns and their correlation with adolescent behavior and beliefs. Journal for the Scientific Study of Religion, 36(3), 372-381. doi: $10.2307 / 1387855$ 
Moretti, M. M., \& Peled, M. (2004). Adolescent-parent attachment: Bonds that support healthy development. Paediatrics \& Child Health, 9(8), 551-555. doi: 10.1093/pch/9.8.551

Okagaki, L., Hammond, K. A., \& Seamon, L. (1999). Socialization of religious beliefs. Journal of Applied Developmental Psychology, 20(2), 273-294. doi: 10.1016/S0193-3973(99)00017-9

Oman, D., \& Thoresen, C. E. (2003). Authors' response: The many frontiers of spiritual modeling: Reply. International Journal for the Psychology of Religion, 13(3), 197-213. doi: 10.1207/S15327582IJPR1303_04

Ozorak, E. W. (1989). Social and cognitive influences on the development of religious beliefs and commitment in adolescence. Journal for the Scientific Study of Religion, 28(4), 448-463. doi: $10.2307 / 1386576$

Pearce, L. D., \& Denton, M. L. (2011). A faith of their own: Stability and change in the religiosity of America's adolescents. New York, NY: Oxford University Press.

Roehlkepartain, E. C., Benson, P. L., King, P. E., \& Wagener, L. M. (2006). Spiritual development in childhood and adolescence: Moving to the scientific mainstream. Dalam E. C. Roehlkepartain, P. E. King, L. M. Wagener, \& P. L. Benson (Eds.), The handbook of spiritual development in childhood and adolescence (hlm. 1-15). Thousand Oaks, CA: Sage Publications.

Santrock, J. W. (2009). Adolescence (13th ed.). New York, NY: McGraw-Hill.

Sax, L. J., Astin, A. W., Korn, W. S., \& Mahoney, K. M. (1999). The American freshman: National norms for fall 1998. Los Angeles, CA: UCLA.

Schwartz, K. D. (2006). Research: Transformations in parent and friend faith support predicting adolescents' religious faith. The International Journal for the Psychology of Religion, 16(4), 311-326. doi: 10.1207/s15327582ijpr1604_5

Schwartz, K. D., Bukowski, W. M., \& Aoki, W. T. (2006). Mentors, friends, and gurus: Peer and nonparent influences on spiritual development. Dalam E. C. Roehlkepartain, P. E. King, L. M. Wagener, \& P. L. Benson (Eds.), The handbook of spiritual development in childhood and adolescence (hlm. 310-323). Thousand Oaks, CA: Sage.

Wahib, A. (2015). Psikologi agama: Pengantar memahami perilaku agama. Semarang: Karya Abadi Jaya.

Wilson, J., \& Sherkat, D. E. (1994). Returning to the fold. Journal for the Scientific Study of Religion, 33(2), 148-161. doi: 10.2307/1386601 